\title{
Data from Selected U.S. Geological Survey National Stream Water-Quality Monitoring Networks (WQN) on CD-ROM
}

\author{
U.S. Department of the Interior
}

U.S. Geological Survey

\section{BACKGROUND}

During the past 30 years, the U.S. Geological Survey (USGS) has operated two national stream water-quality networks, the Hydrologic Benchmark Network (HBN) and the National Stream Quality Accounting Network (NASQAN). These networks (Fig. 1) were established to provide national and regional descriptions of stream water-quality conditions and trends, based on uniform monitoring of selected watersheds throughout the United States, and to improve our understanding of the effects of the natural environment and human activities on water quality. The HBN, consisting of 63 relatively small, minimally-disturbed watersheds, provides data for investigating naturally-induced changes in streamflow and water quality and the effects of airborne substances on water quality. These watersheds range in size from 2 to 2,000 square miles with a median drainage basin size of 57 square miles. NASQAN, consisting of 618 larger, more culturallyinfluenced watersheds, provides information for tracking water-quality conditions in major U.S. rivers and streams.
Drainage basins range in size from 1 square mile to 1.2 million square miles with a median drainage basin size of about 4,000 square miles. NASQAN and HBN watersheds represent a diverse set of climatic, physiographic, and cultural characteristics.

Stream water-quality measurements are available for the approximate periods 1973 to 1995 for NASQAN and 1962 to 1995 for HBN. The data reflect sampling for a variety of water properties over a wide range of streamflow conditions using relatively consistent sampling and analytical methods. Figures 2 and 3 display the number of water-quality analyses by year for NASQAN and HBN, respectively. These data, collectively referred to as Water-Quality Networks (WQN), are contained in the two-CD-ROM set USGS Digital Data Series DDS-37, "Data from Selected U.S. Geological Survey National Stream Water-Quality Monitoring Networks (WQN)," by R.B. Alexander, J.R. Slack, A.S. Ludtke, K.K. Fitzgerald, and T.L. Schertz.

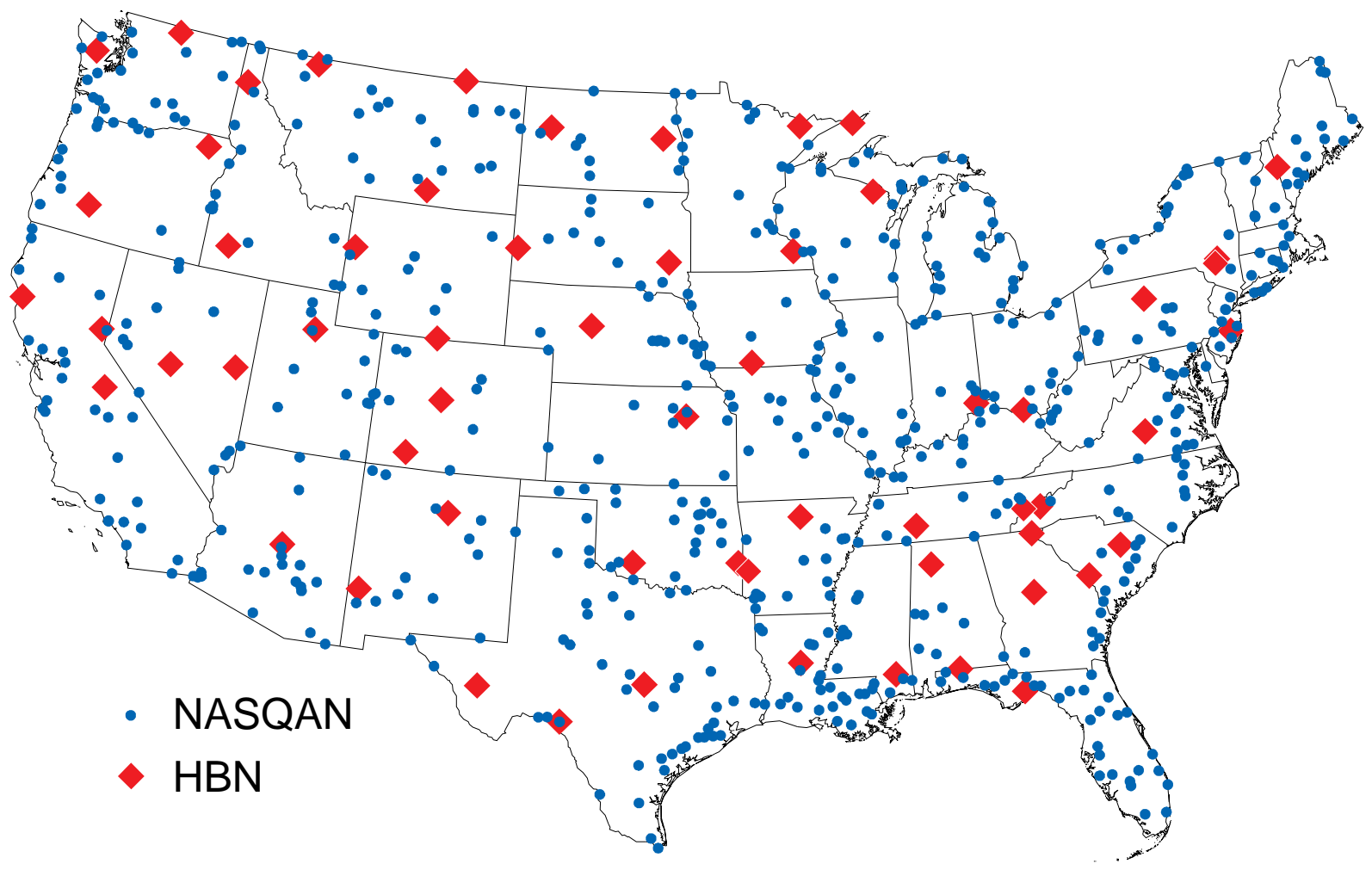

Figure 1. NASQAN andHBN station locations in the conterminous United States. 


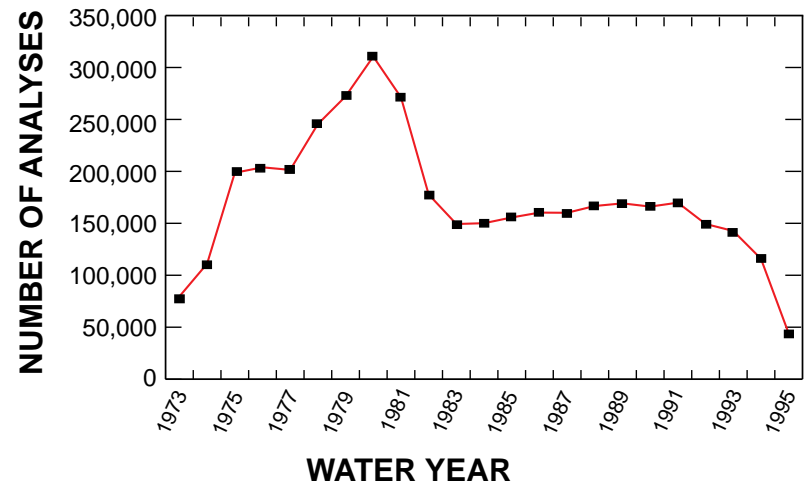

Figure 2. Number of NASQAN water-quality analyses by year.

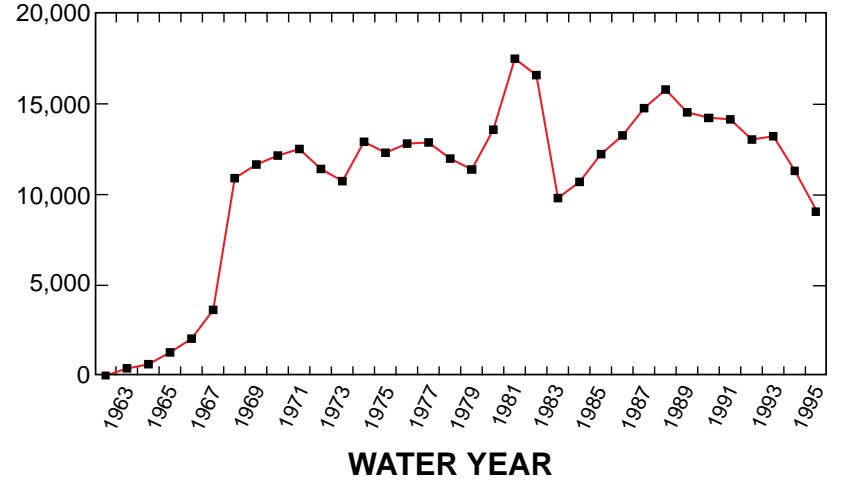

Figure 3. Number of HBN water-quality analyses by year.

\section{CONTENTS OF THE WQN CD-ROMS}

The CD-ROMs include the following:

- Uniformly-sampled (i.e., semi-annually to monthly) data for 63 physical, chemical, and biological properties of water (122 water constituents including the dissolved, suspended, and total forms); these data include physical measurements (e.g, temperature, instantaneous streamflow, specific conductance, suspended sediment), major ions, nutrients, organic carbon, radiochemicals, biological measurements (e.g., fecal bacteria, phytoplankton), and inorganic trace elements.

- Daily mean values of streamflow for similar time periods as the water-quality records.

-Water-quality and streamflow station attributes including drainage area, latitude, longitude, dates of station operation, county, state, hydrologic unit code (HUC), drainage basin population for 1990 and land-cover statistics for 1987.

- The sample-collection agencies, laboratories, laboratory analytical methods, and the measurement accuracy associated with the stream water-quality data; measurement accuracy can be evaluated using laboratory quality-control data based on regular measurements of standard reference water samples for 34 nutrients, major dissolved ions, and trace elements for water years 1985-1995 (Oct. 1, 1984 to Sept. 30, 1995).

- Documentation of important changes in field and laboratory methods, constituent coverage, network operations, reporting conventions, and sample contamination that may affect the use and interpretation of the stream water-quality data.

- USGS Open-File Report (OFR) 96-337 entitled "Data from Selected U.S. Geological Survey National Stream Water-Quality Monitoring Networks (WQN) on CDROM," by R.B. Alexander, A.S. Ludtke, K.K. Fitzgerald, and T.L. Schertz; the report describes the history of the national networks, characteristics of the water-quality, streamflow, and quality-assurance data, statistical methods for using laboratory quality-control data to evaluate the accuracy of stream water-quality measurements, and a bibliography of publications relevant to the national networks.

- Two forms of the data: (1) an ASCII form accessible via user-supplied software including Web browser (e.g., Mosaic, Netscape Navigator, or Microsoft Internet Explorer), word processor, spreadsheet, or statistical analysis software, and (2) a DOS version (operational on Windows systems) that includes software capable of browsing text files and retrieving and printing data according to user-specified criteria.

The CD-ROMs (DDS-37) may be purchased from the Branch of Information Services (below). The ASCII form of the CD-ROM data and the report (OFR 96-337) are also available electronically on Internet via anonymous FTP to directory wqn96 on ftprvares.er.usgs.gov or by Web browser to URL http://wwwrvares.er.usgs.gov/wqn96/. Public inquiries about the CD-ROM may be directed to the National Water Information Center at (800) 426-9000.

-R.B. Alexander, J.R. Slack, A.S. Ludtke, K.K. Fitzgerald, and T.L. Schertz
For additional information, write to:

U.S. Geological Survey

National Water Quality Assessment Program

MS 413 National Center

Reston, Virginia 20192
To purchase reports (OFR 96-337) or computer discs (DDS-37), contact:

U.S. Geological Survey

Branch of Information Services

Box 25286

Denver, Colorado 80225-0286

800-435-7627
Fact Sheet FS-013-97

Printed February 1997 